\title{
Memory is a Weapon: Ton Steine Scherben's Use of WWII Memory in the Political Upheavals of the 1970 s
}

\author{
SIDNEY KÖNIG
}

\begin{abstract}
This paper examines the relationship of 1970s German "Agit-Rock" band Ton Steine Scherben with the memory of WWII. I use this as an entry point to a more general consideration of the role of WWII memory in pre-unification West German society and of the contribution of popular music to an interrogation of the political status of such memory. Throughout their career, the "Scherben" have made continuous implicit or explicit references, in songs, interviews and other media, to the horrors of WWII and their legacy in the German postwar political and cultural landscape. On the basis of archival materials, music analysis of selected songs, and original interviews with band members, I explain why and how the Scherben used the memory of WWII to further their leftist countercultural agenda, and elaborate on the war's presence (or absence) and relevance in 1970s German society and its implications for the conflicts between war and postwar generations. Narrative analysis will provide insights into the value constructions of the time, identifying the usage of WWII memory as a popular weapon in German political confrontations, and locating the Scherben's role and impact within these conflicts.
\end{abstract}

\section{Introduction: Shards of a Hidden Past}

The "Agit-Rock" band Ton Steine Scherben is one of the most unusual musical phenomena in German postwar history. A highly politicized rock band, their music is often considered the de facto soundtrack of the political upheavals of 1970s West Germany, ${ }^{1}$ and is still frequently played at demonstrations. Their singular status in German music culture is evidenced by numerous cover versions of their songs by artists of nearly all genres of popular music. ${ }^{2}$ There can be little doubt about their influence on German pop music culture. Yet, despite their lasting impact, the Scherben were never commercially successful. ${ }^{3}$ They were never signed to a major label, opting instead to produce and distribute their music themselves via leftist bookstores, and the band's staunchly anti-capitalist stance and rootedness in the 1970s West German leftist scene often led them to play in support of causes that involved little to no compensation. Given these factors, the fact that the Scherben are so well known is a testament to how much their music reverberated within their generation and for subsequent generations.

Reverberation, in a metaphorical sense, will also be a key component of my analysis here. While the

\footnotetext{
${ }^{1}$ Timothy Brown, "Music as a Weapon? "Ton Steine Scherben” and the Politics of Rock in Cold War Berlin," in German Studies Review 32, no. 1 (2009): 3.

${ }^{2}$ According to Rio Reiser biographer Hollow Skai, the website www.riocover.de has registered more than 650 cover versions of songs from both the Scherben and Rio Reiser (Skai, Rio Reiser. Das alles und noch viel mehr. [Bremen: Fuego, 2016], 210). The website itself at present states there are "over 800 published and 500 unpublished cover versions of Rio Reiser and Ton Steine Scherben” (Christian Noller, riocover.de, accessed May 2, 2019, http://www.riocover.de/1.htm, my translation). A number of citations throughout this article as well as all quoted passages from interviews are translated from the original German. Unless otherwise noted, all translations are my own.

${ }^{3}$ Guitarist and singer Rio Reiser (real name Ralph Möbius) later had some mainstream success as a solo artist in Germany with songs like "König von Deutschland" (King of Germany) and "Junimond" (June Moon), and after his untimely death in 1996, became a revered figure in Germany akin to musicians like Jimi Hendrix or Jim Morrison.
} 
Scherben remain the central focus, the analysis itself is about how their music (and to a certain extent their lifestyle) reflected and reverberated aspects of WWII memory in the West German lifeworlds of the 1970s. The Scherben may seem a curious choice for such an analysis given that they rarely explicitly referenced WWII in their music, especially compared to contemporaries like the "Liedermacher" (singer-songwriters) Hannes Wader, Wolf Biermann, or Franz Josef Degenhardt, in whose songs the subject is more prominently dealt with. ${ }^{4}$ This is where what I call memory reverberation comes into play: The FRG (Federal Republic of Germany) of the 1960s and 1970s had only just begun to develop the memory culture we know today. ${ }^{5}$ This development was opposed by a generation of people whose refuge from their traumatic war experiences and the ideological confusion after the war had been a return to traditional values, which resulted in sweeping conservatism. A sizable number of Germans had internalized Nazi ideology to a point where it continued to inform their political opinions, cultural preferences, and, significantly, their social interactions. The reaction of younger generation(s) to this sociocultural climate is in turn an echo of the impact of WWII on the population. ${ }^{6}$ The music of the Scherben is a reflection of these reverberations of the war among the postwar generation. Throughout my analysis, I intend to show that memory culture was not necessarily limited to "official" or intentional moments of remembrance, but also can also be read between the linesechoes in a subtext, as it were. This specific type of memory transmission is framed by the larger concept of sounding memories discussed in this volume in that it is very much memory that has taken musical form. The Scherben's music - as such a transmission-represents a creative (re)sounding of memory that demonstrably enabled the forging of collective bonds for FRG youth of the 1970s particularly.

After a brief look into the theoretical background of my approach, I provide historical context regarding the sociocultural conditions of the FRG in the 1970s. This is followed by a more detailed description of the Scherben's lifeworld and how it impacted their cultural production-specifically their music, some examples of which I will analyze in depth. I close my analysis by reflecting on the legacy of the Scherben and their effect on WWII memory. Throughout the article, I will illustrate how the effects of WWII memory reverberations found cultural and social expressions in the lifeworld and music of the Scherben. We must remember that while memory is not necessarily something that is wanted, and is indeed often willfully forgotten or repressed, it tends to find its way into our lives in the way we talk, the stories we tell, and the songs we sing.

\section{A Narrative Approach in Memory Studies}

In this chapter, I mainly discuss memory studies as approached via a methodologically focused narrative mode of research, which serves as my main instrument for analysis. I will furthermore introduce the concept of memory reverberation as an analytical category, in order to explain the unusual role of WWII memory in the music and cultural production of the Scherben.

Narratives, Ann Rigney argues, form the very basis of memory culture:

\footnotetext{
${ }^{4}$ David Robb, “The Early Protest Song of the Late 1960s and Early 1970s_Franz Josef Degenhardt and Ton Steine Scherben,” in German Pop Music: A Companion, ed. Uwe Schütte (Berlin: De Gruyter, 2017), 47, https://doi.org/10.1515/9783110425727-003.

${ }_{5}^{5}$ Martin Ringsmut in this volume points out this circumstance specifically regarding the "forgotten" memory of the genocide of Sinti and Roma during WWII.

${ }^{6}$ Bernhard Giesen, "The Trauma of Perpetrators. The Holocaust as the Traumatic Reference of German National Identity," in Cultural Trauma and Collective Identity, ed. Jeffrey Alexander, Ron Eyerman, Bernhard Giesen, Neil Smelser, and Piotr Sztompka (Berkeley: University of California Press, 2004), 128, https://doi.org/10.1525/california/9780520235946.003.0004.
} 
"Narrative" is a key concept in cultural memory studies. It is generally assumed that recollections are stored and transmitted primarily through stories, even when these take the condensed form of a photograph. An important body of scholarship, originating in philosophy of history but now assimilated into cultural studies, relates to what has been called "the value of narrativity in the representation of reality." ... Behind these discussions is the idea that "narrativity" is a cognitive scheme rather than a property of events; accordingly, that experiences are not in themselves stories, but become narrativized through the application of models of storytelling which help turn events into meaningful structures. ${ }^{7}$

Stories are representations of reality, "functionally coherent representations of sequences of events," operating as "the means of human sense-making" in culture and society. ${ }^{9}$ This applies to all forms of memory culture. Externalized memory, no matter its contents or characteristics, necessarily has to contain or refer to narrative elements. This also includes phenomena like memorials, which are references to or physical manifestations of narratives. Rigney provides an analytic approach to this:

Already in their very composition, then, narratives can be said to be 'premediated' ... by the memory of earlier stories which provide conditions of possibility for the articulation of new ones. What at first sight may seem to be unique narratives are actually based on a sedimentation of earlier ones ...; the sense of singularity arises from the foregrounding of the specificity of the case against the background memory of similar occurrences. ${ }^{10}$

Memory as expressed in narrative also feeds back into it, establishing narrative structures, modes of thought, genre conventions and similar frameworks for new stories. In fact, Rigney argues that

a memory must be kept alive through repeated acts of recall if it is not to be de facto forgotten by becoming culturally insignificant and ceasing to produce responses. The key to memory is not in storage (the fact of information being archived) but in the capacity of a particular story to stimulate its own reproduction in a new form: to procreate. . . ${ }^{11}$

Thus, a constant re-iteration of narratives is required to secure the continuation of memories. This also means that memories change over time and are generally remembered according to the interests of the agent re-telling the story. As Astrid Erll points out: "Individual and collective memories are never the mirror image of the past, but rather an expressive indication of the needs and interests of the person or group doing the remembering in the present." 12

This leads me to my proposed additional terminology of memory reverberation: it refers to a memory that seems curiously absent from discourse, but nevertheless has significant effects on the society in which it is contained. It concerns events that are known and relevant to a significant number of people, but are either not directly narratively negotiated or are negotiated around, for one reason or another. In my example, Ton Steine Scherben, these reverberations concern aspects of WWII memories in the postwar FRGmemories that are either narratively suppressed or at the very least concealed, but - and this is the key factor-still bubble to the surface. I argue that these reverberations were a significant enough factor to affect

\footnotetext{
${ }^{7}$ Ann Rigney, “Cultural Memory Studies. Mediation, Narrative, and the Aesthetic," in Routledge International Handbook of Memory Studies, ed. Anna Lisa Tota and Trever Hagen (London: Routledge, 2016), 70.

${ }^{8}$ Ismay Barwell, "Understanding Narratives and Narrative Understanding," in The Journal of Aesthetics and Art Criticism 67, no. 1 (2009): 49, https://doi.org/10.1111/j.1540-6245.2008.01334.x.

${ }^{9}$ Corinne Squire, "Experience-Centered and Culturally-Oriented Approaches to Narrative," in Doing Narrative Research, ed. Molly Andrews, Corinne Squire, and Maria Tamboukou (Los Angeles: SAGE Publications, 2008), 43, https://doi.org/10.4135/9780857024992.d4.

${ }^{10}$ Rigney, "Cultural Memory Studies," 70.

${ }^{11}$ Rigney, "Cultural Memory Studies," 68.

${ }^{12}$ Astrid Erll, Memory in Culture (Basingstoke, UK: Palgrave Macmillan, 2011), 8 https://doi.org/10.1057/9780230321670.
} 
multiple generations of people in different ways. To my mind, it is this reverberatory effect of Scherben's music that carries it into the realm of sounding memories, as opposed to merely containing vague historical references or memorial connotations.

The development of the memory reverberation concept is based on a thorough review of the literature provided by actors involved in (or related to) the lives and cultural production of the Scherben in the 1970s; an analytic consideration of that cultural production; and interviews with some of the protagonists, namely with the first Scherben drummer Wolfgang Seidel, later drummer Funky Götzner, and bassist Kai Sichtermann, in 2018.

\section{(West-)German Lifeworlds from the Postwar Period to the 1970s}

Bernhard Giesen speaks of a "coalition of silence" in postwar Germany, ${ }^{13}$ specifically relating to the war generation(s). The general understanding among Germans of those generations was a selective avoidance of certain war related topics (namely those that might implicate Germans in war crimes and other atrocities), also leading to the construction of narratives that served the deflection of guilt. ${ }^{14}$ While, as Robert Moeller agues, the memory of the allied bombing campaigns, the suffering of German displaced people from the East, and the Soviet imprisonment of German POWs were a subject of active debate and cultural representation in the 1950s and 1960s, the atrocities committed by the Nazi regime were rarely discussed, and victims of Nazi crimes remained largely invisible in the early FRG. ${ }^{15}$ Narrative schemata were employed to accomplish silencing and deflection, which-combined with the everyday elements of authoritarianism at the time-are also significant for my analysis of the Scherben's music.

The idea that memory is occasionally circumvented can be found in Jeffrey Goldfarb's considerations of memory, specifically with reference to Paul Ricoeur:

Ricoeur (2003) tells us that "the memory image is present in the mind as representing something which is no longer there but which has been" and goes on to say, "This 'having been' is what memory tries to recover; memory claims to be faithful to this 'having been."” Ricoeur continues: "Memory, then, was not only taught by history but wounded by it." Memory exhibits wound memory and memory wounds the exhibits. Re-remembering is challenged by inconvenient material, and we forget to remember the inconvenient for our present purposes. And things do not always work out as expected. ${ }^{16}$

This somewhat cryptic phrasing reflects something that Giesen says about the construction of narratives in the German postwar generations: "Faced with those who could not be co-opted into the coalition of silence, Germans required a new exculpatory narrative. Postwar Germany constructed this narrative by primordializing the opposition between oppressors and the people." ${ }^{\prime 7}$ Thus by portraying the head Nazis, Hitler in particular, as dangerous seducers and themselves as perhaps gullible, but honorable people, ${ }^{18}$ postwar Germans could circumvent the "inconvenient material" presented by critics who refused to be part of their coalition of silence.

\footnotetext{
${ }^{13}$ Giesen, "The Trauma of Perpetrators," 117.

${ }^{14}$ Ibid., 118.

${ }^{15}$ Robert Moeller, War Stories: The Search for a Usable Past in the Federal Republic of Germany(Berkeley: University of California Press, 2001).

${ }^{16}$ Jeffrey Goldfarb, “Against Memory,” in Routledge International Handbook of Memory Studies, ed. Anna Lisa Tota and Trever Hagen (London: Routledge, 2016), 61.

${ }^{17}$ Giesen, “The Trauma of Perpetrators," 119.

${ }^{18}$ Ibid.
} 
This narrative schema essentially allowed them to "forget to remember." Goldfarb adds:

The social work needed to forget is sometimes as important as the work needed to remember, noting that it is complicated and that the balance cannot be decided definitively. The memory is indeed socially constructed but it includes great contradictions and tensions. ${ }^{19}$

Suppressing the memory of an event as large-scale and horrible as the Holocaust indeed requires a significant amount of social work; therefore, the coalition of silence became a necessity, which in turn required the construction of narratives that worked to circumvent the topic or redirect the focus of discourse-by, for example, pointing out the suffering of displaced Germans and POWs.

Beginning in the late 1950s, there were significant challenges to the coalition of silence. Students researched and criticized the more or less uninterrupted employment of professors, medical doctors, and judges who had been involved in the Nazi regime. Charges were even filed against certain individuals. ${ }^{20}$ One of the most visible attacks on the coalition of silence was the traveling exhibition "Ungesühnte Nazijustiz" (Unpunished Nazi Judiciary) from 1959 to 1962, set in motion by then-student Reinhard Strecker. The exhibition was the result of his reaction to an appeal by the Bundestag from 1958, "for which interested citizens could highlight those questions of public interest that German politics did not pay enough attention to." ${ }^{21}$ These and other similar processes ${ }^{22}$ fed into the political self-conceptions of the postwar generation, who, according to political scientist Volker Paulmann, arrived at "a political position ..., which demanded not only taking responsibility for national socialism on an individualbiographical level, but also in society as a whole." ${ }^{23}$ Obviously, this served as a major point of contention between generations.

Accounts from both (former) members of the Scherben (such as Wolfgang Seidel, see below) and their social environment reflect such contentions. Achim Müller, born in Berlin-Kreuzberg and former member of the apprentice theater group Rote Steine, ${ }^{24}$ which in part spawned the Scherben, describes generational tensions in his youth in his own theatrical way:

A typical scene at the workplace proceeds the following way: A painter's apprentice is-apart from fetching beer and buns-also required to assist the journeymen, for example by sweeping or carrying buckets of paint to the fourth floor. He talks to the master craftsman and asks him at what point he can actually learn something, perhaps mix paint or do the paperhanging for a room himself. The master craftsman: 'You will do what I tell you. That's the way we've always done it. Just paint the walls white for now; once you've done that for half a year, we'll see. Now shut up and get on with it, or there'll be hell to pay. And in general: Don't you dare talk to me like that. If we had done that under Adolf. . ."25

\footnotetext{
${ }^{19}$ Goldfarb, “Against Memory,” 62.

${ }^{20}$ Jan Lohl, ““...die ganze Nazi-Scheiße von gestern...' Protest und Phantom - Die Protestbewegungen der 1960er Jahre aus der Perspektive der psychoanalytischen Generationenforschung," in Psychosozial 124: Unheimliche Wiedergänger? Zur Politischen Psychologie des NS-Erbes in der 68er-Generation, ed. Markus Brunner and Jan Lohl (Giessen: Psychosozial Verlag, 2011), 11.

${ }^{21}$ Lohl, "Nazi-Scheiße," 11.

${ }^{22}$ Some of these processes are elaborated upon in Dagmar Herzog, Sex After Fascism: Memory and Morality in TwentiethCentury Germany (Princeton, NJ: Princeton University Press, 2007), 221, https://doi.org/10.2307/j.ctt4cgbqw.

${ }^{23}$ Lohl, "Nazi-Scheiße," 12.

${ }^{24}$ Ton Steine Scherben grew out of two different leftist theater groups: the Rote Steine and Hoffmann's Comic Teater; see Kai Sichtermann, Jens Johler, and Christian Stahl, Keine Macht für Niemand. Die Geschichte der "Ton Steine Scherben" (Berlin: Schwarzkopf \& Schwarzkopf, 2000), 17.

${ }^{25}$ Achim Müller, "Eisen erzieht," in Scherben. Musik, Politik und Wirkung der Ton Steine Scherben, ed. Wolfgang Seidel (Mainz: Ventil Verlag, 2005), 118.
} 
Naturally the reference to Hitler in the last half sentence is interesting for my context, but it is the general attitude depicted in the scene that makes Müller's description rather telling. Müller-as not only a contemporary but also collaborator of the Scherben-describes an authoritarianism here that seems to be understood as a normal social interaction, specifically in the context of hierarchically charged relationships. Müller further comments on the situation at the workplace: "It had something of a military tone." 26 The military connotation is significant, because it directly refers back to wartime and the Nazis in general. Military drill, absolute obedience and strict adherence to hierarchy were central pillars of Nazi self-conception even before the war, and are echoed in the behavior of fathers, teachers, foremen and master craftsmen.

Original Scherben drummer Wolfgang Seidel describes similar memories:

In schools as well as in families, social interaction was still very authoritarian. I remember with horror some family celebrations, where, once the cognac was put on the table after dinner, the men began talking about their war experiences. Obviously the German soldier was the best soldier-the Ami [Americans] had just had more material and the Iwan [Russians] had had more people. And once they had had enough to drink, mistakes were admitted. They fought about whether it would have been better to have gotten together with the Russians to fight against the Amis. Or better the other way around. Anti-Semitism? There were barely any Jews left in the country, but they still said that Jews were only after the money. To accept the small bit of reparation-peanuts compared to what had been looted-for that, they would have had to have some feeling for their own responsibility. Were they all Nazis? Were they all evil? No, but they were also not the opposite. They felt they were victims. They asked time and again what they, as the "small folk," could have done. Therefore, the lesson they took from the story was to do nothing. To not even think about it. "The top brass" would do whatever they wanted, anyway. And who was "the top brass"? Nazi ideology had not disappeared without a trace after 1945 , nor had its actors. ${ }^{27}$

Seidel concisely portrays the narrative strategies of a war generation desiring to construct themselves as victims. Evasion and the shifting of blame characterize the narrative strategies employed. There is no sense of confronting the matter aside from shifting the blame to "the top brass." Even the admission of mistakes stays contained within this framework. There is a form of distancing from the regime via the construction of the "small folk" vs. "top brass" opposition that, however, is undermined by the speculation about "getting together with the Russians," putting the commenters back in the role of actors (and perpetrators) and not victims. Self-perception here seems entirely confused, and just as Seidel argues, the way around this contradiction is "to do nothing, to not even think about it." This also shows that narrative strategies in this case do not necessarily need to be logically consistent or free of contradictions to be effective. On the contrary, generally simple narratives — as collective constructions of memory—work best, because they provide the easiest option of a "way out;" complex narratives are more difficult to adapt.

Scherben bassist Kai Sichtermann describes the time from his perspective:

I was born in 51 . And when I grew up, the teachers were still very authoritarian. We were still beaten; there was a cane in the class cupboard. My father would hit me as well, but only when I had done something. Everything was still very affected by both the wars-there were two warsand this was not only because there were seventy million dead, but also at least as many

\footnotetext{
${ }^{26}$ Müller, "Eisen erzieht," 119.

${ }^{27}$ Wolfgang Seidel, "Berlin und die Linke in den 1960ern. Die Entstehung der Ton Steine Scherben," in Scherben. Musik, Politik und Wirkung der Ton Steine Scherben, ed. Wolfgang Seidel (Mainz: Ventil Verlag, 2005), 37.
} 
traumatized people. That had its aftereffects. ${ }^{28}$

The long-term effects of the war (among them its memory reverberations) were still very present in the youth and adolescence of the postwar generation (a term I use here as shorthand for Germans born between ca. 1945 and 1955), of which Sichtermann is a contemporary witness. It is significant that Sichtermann himself directly relates the behavior of his parents and teachers towards him to war trauma. The postwar generation was clearly aware of the impacts of the war memory on themselves. This is the main (or at least for the protagonists concerned the most significant) way in which the war reverberated into their generation. There are numerous similar stories, both from my interview partners and in the literature ${ }^{29}$ concerning the authoritarianism that young people were facing in the 1960s and 1970s. Despite all deflections, the sociocultural impact of war and indoctrination found outlets that significantly affected younger generations. Both authoritarianism and narrative modes of deflection characterize how WWII memory reverberated from the war generation to their offspring. A closer look at the lifeworld of the Scherben and their contemporaries illustrates this process quite succinctly.

\section{The Scherben, Their Lifeworld and WWII Memory Reverberations}

\section{The Scherben's domestic and socio-cultural contexts of the late 1960s and early 1970s}

Rooted in lived experience, the engaged theater of the Rote Steine mirrored a key theme of the sixties revolution in West Germany, that of self-liberation through action. In speaking the previously unspeakable, making visible previously taken-for-granted authoritarian relationships between boss and worker, teacher and student, parent and child, Hoffmann's Comic Teatre [sic] and the Rote Steine penetrated to the heart of the New Left understanding of locating the political in the everyday. ${ }^{30}$

Arguably, for the adolescents of the 1960s and 1970s-specifically for those from working class households - the political was the everyday. It was precisely where their grievances with society were located. This may be one of the reasons why the Scherben rarely commented on large-scale politics in their music - the problems they and their audience were facing had a more immediate quality than a war in a distant country or decisions on the grand political stage. This however does not mean that the concerns of the Scherben, and by extension their audiences, were negligible matters; the authoritarianism young people in the FRG society of the 1960s and 1970s were perceiving in classrooms, at work, and at home was for them far from trivial. It created an oppressive, inflexible, and altogether grey lifeworld for them (as comments from several of the contemporary witnesses in this article quite succinctly illustrate). This is part of how war significantly affected young people's lives through the attitudes of the older generation, in spite of any attempts at silencing memories.

Given this context, it is perhaps no coincidence that the very name of the Scherben itself obliquely refers to the war. There are several origin stories about the name "Ton Steine Scherben," depending on which band member or chronicler one asks. The most interesting one for my purposes is the one by Seidel:

Rio later explained that he stumbled over the words while reading a book about Heinrich

\footnotetext{
${ }^{28}$ Kai Sichtermann, interview, August 20, 2018.

${ }^{29}$ See for example Sichtermann, Keine Macht für Niemand or Seidel, "Berlin" and "Scherben...".

${ }^{30}$ Brown, "Music as a Weapon?," 5.
} 
Schliemann, excavator of the ruins of Troy. Schliemann had commented on his discovery with the words: what we found was clay, stones, and shards. We were not archaeologists, but there was still enough debris all around us. But the things that lay there in pieces also deserved to. Didn't the Nazis sing that they would continue marching "bis alles in Scherben fällt" [until everything breaks into shards]? ${ }^{31}$ With this, these self-appointed Übermenschen planning to Germanize the world had clearly stated that they could not be stopped any other way. It was part of the work of archeologists to put the pieces back together again. However, we certainly did not want to put back together those shards that were the result of the German delusion. ${ }^{32}$

In this interpretation, the very name of the band invokes the memory of WWII. It is interesting (if obvious, given the reference to Schliemann) that Seidel chose the analogy of the Scherben as archeologists. To portray them as such says something about their relationship to the country, specifically implying the intention to dig out and deal with the buried past. Seidel adds: "The band's name was an attempt to connect to a positive history of resistance, from the peasant wars to the Edelweiß-Piraten." ${ }^{33}$ This makes it even more curious that the Scherben rarely referred to the war or the atrocities committed by the Nazis directly in their songs. But what they addressed instead - the situation in West Germany at the time-is understood as a more or less direct result of the war and the lingering influence of Nazi ideology. Wolfgang Seidel writes:

My memories of postwar Germany are all grey. Not only because the TV, which only slowly came into our lives, broadcast in black and white. There was no color in life. Nor was there color in words. It was the time of frightened assimilation and the obeying of iron etiquette. And it was the time of the great silence about what was below this frightened surface, the bodies in the basement. The grownups, the teachers, judges, who demanded one stood up when they entered the room-one only suspected.... The results of these delusions of grandeur were still visible all over Berlin. Entire streets of houses were wastelands, on which the debris of the war had been piled without being used somewhere else.... One of the first color stains in my life was the blue-white-red circle on The Who drummer Keith Moon's shirt. We could mysteriously see these colors, despite "Beat Club" being broadcast in black and white at the time. ${ }^{34}$

The first impulse for a transformation of this dreary scenario of uneasy silences comes from outside Germany-in the form of rock 'n' roll. Seidel's color analogy suggests that the music profoundly changed young people's perceptions of the world, and with it came a change in expectations. Sichtermann reports similar feelings:

And the music just. . rock 'n' roll just spoke to me. And it's ... Rock 'n' roll started in the mid-'50s. This was a cultural revolution up until the '70s . . up until punk, I'd say. And I was inspired by the music, despite me speaking English rather badly. And then in the '60s it started with the hippies, the student unrest, the Vietnam War, the demonstrations against it. That was a bunch of stuff that just grabbed me. And then I went to Berlin in '69, met Rio Reiser, and we founded the Scherben. And of course all that played a role in it. It was pretty similar with Rio and [Scherben guitarist R. P. S.] Lanrue. ${ }^{35}$

For the Scherben, rock 'n' roll becomes the voice in the silence, the color in the void. This also fits in with

\footnotetext{
${ }^{31}$ This is a reference to a line from Nazi songwriter Hans Baumann's song "Es zittern die morschen Knochen” (brittle bones are trembling; "HJ-Lieder von Hans Baumann," Jugend! Deutschland 1918-1945, NS-Dokumentationszentrum der Stadt Köln, accessed October 24, 2020, https://jugend1918-1945.de/portal/jugend/thema.aspx? root=26636\&id=4922).

${ }^{32}$ Wolfgang Seidel, "Scherben...," in Scherben. Musik, Politik und Wirkung der Ton Steine Scherben, ed. Wolfgang Seidel (Mainz: Ventil Verlag, 2005), 78.

${ }^{33}$ Ibid., 82.

${ }^{34}$ Seidel, "Berlin," 30.

${ }^{35}$ Kai Sichtermann, interview, August 20, 2018.
} 
the unwillingness to rebuild "the German delusion" in that the new music came from outside Germany and was clearly different from German music at the time. Ethnomusicologist Julio Mendívil explains:

The German music industry experienced such a profound crisis after the allied victory that it drew upon unpublished songs from the final years of the war. Nostalgia, distance and Heimat were some of the major topics at this time, just as they had been in the Schlager of the Nazi era. ... Until the arrival of rock 'n' roll, dance music was made by adults for an adult audience. However, with the advent of rock 'n' roll, the music industry began to pay attention to a younger audience which saw waltz, polka, fox, rumba and polonaise as antiquated forms of music for an older generation. ${ }^{36}$

Rock 'n' roll was music made for young people, positioned squarely against the grey world of adults. The electrifying effect it had on the German youth is clearly visible in the comments of Seidel and Sichtermann. Rock 'n' roll served as an act of liberation from the world of adults. It was a newfound freedom that also enabled them to talk about "forbidden" issues: "Having grown up in a society whose favorite activity was silence, there was a great desire to talk to one another, to talk about everything the country was otherwise silent on, from the Nazi past to your own body." ${ }^{37}$ And not just the war; the silence itself was questioned. Journalist Hartwig Vens comments:

The conditions that needed to be gotten rid of were those of the parent generation, their way of life and their values. The fascist continuity that manifested itself through officials in every part of public life also showed in the lifeworld, in families, youth clubs and companies, by way of authoritarian structures and an atmosphere characterized by pressure, silence and joylessness. Exactly against such conditions beat and rock music seemed to have been invented-a loud, vulgar language that parents did not understand and caused provocation, polarization, and separation for that reason alone. ${ }^{38}$

This almost teleological interpretation of the process makes clear that rock 'n' roll was to a certain extent perceived as a tool—or a weapon-against fascist continuities and the authoritarianism young people were facing. ${ }^{39}$ Indeed, the Scherben's manifesto, first published in the leftist underground magazine Agit 883, begins with the sentence "Musik ist eine Waffe!" (music is a weapon). According to the manifesto, the Scherben's target audiences are "people from our generation: apprentices, rockers, young workers, criminals, people in and from foster homes" authoritarianism in the workplace, at home, and in homes. That seemed to hit a nerve. Brown writes:

The band reported selling 10,000 copies of the "Macht kaputt, was euch kaputt macht" single, and a similar number of the "Warum geht es mir so dreckig" LP. By the end of the decade, Ton Steine Scherben had sold 300,000 of its own albums with no advertising and next-to-no radio airplay. $^{41}$

The Scherben's success in spite of their limited means of distribution shows that a radical expression of

\footnotetext{
${ }^{36}$ Julio Mendívil, "Schlager and Musical Conservatism in the Post-War Era," in German Pop Music: A Companion, ed. Uwe Schütte (Berlin: De Gruyter, 2017), 28, https://doi.org/10.1515/9783110425727-002.

${ }^{37}$ Seidel, "Berlin," 28.

${ }^{38}$ Hartwig Vens, “'Unsere Lieder sind einfach, damit viele sie mitsingen können.' Zur Sprache der Scherben,” in Scherben. Musik, Politik und Wirkung der Ton Steine Scherben, ed. Wolfgang Seidel (Mainz: Ventil Verlag, 2005$), 207$.

${ }^{39}$ It has to be pointed out that Vens's interpretation of the historical situation itself follows a narrative construction of memory on the part of someone from the postwar generation. The teleological element in this interpretation serves to construct a generationally based "us vs. them" narrative, painting the older generation as fascist, which in turn casts the younger generation as antifascist resistance.

${ }^{40}$ Agit 883 Nr. 73 (Berlin), December 24, 1970, 5.

${ }^{41}$ Brown, "Music as a Weapon?," 10.
} 
dissatisfaction was something that many young people could identify with, both in terms of sound and message. The Scherben became an oft-requested band at all sorts of political events. They pioneered forms of cultural production that today are usually associated with punk music and culture, such as founding their own label as well as producing and marketing their music themselves. ${ }^{42}$ Indeed, even the sound of their earlier albums is akin to later punk productions (although these characteristics have more to do with pragmatic necessities rather than practical or aesthetic choice). ${ }^{43}$ The political opinions the Scherben expressed in their music were reciprocally informed by interaction with their audiences. Indeed, their manifesto states: "Our audience sets the standard, not some crazy poets. We learned from the audience to make songs; we can only learn from them how to make songs for the people in the future." ${ }^{\text {4 }}$ Stories from people's homes or their workplaces fed back into the lyrics of the band, as is quite visible in songs like "Ich will nicht werden was mein Alter ist" (I don't want to become what my old man is, 1971), "Feierabend" (Closing time, 1972) or "Wir müssen hier raus!" (We have to get out of here!, 1972). All of these songs are about authoritarianism and oppression in one form or another. I will discuss some examples in the following chapter.

Ideologically speaking, the Scherben were influenced by the general trends of the leftist movements at the time. The ideological orientation of the Scherben was (perhaps intentionally) kept vague; in their manifesto, they eschew a rigidly defined ideological framework, rather opting to "support every action that serves the class struggle, no matter which group organizes it." 45

While the Scherben occasionally collaborated with K-Groups (orthodox far left groups in West Germany) and other radical elements of the German left, they never adhered to any strict dogma. In fact, occasionally the Scherben's relationship with K-Groups and other radical leftists would become rather tense; Reiser and Eyber for example describe an interaction with such a group that nearly ended in a fistfight. ${ }^{46}$ Similarly, after early demonstrations of solidarity, the Scherben eventually distanced themselves from the far-left militant organization RAF, ${ }^{47}$ because they "got tired of following the orders of these underground commanders." 48

The historiography of the 1968 movements has been very much focused on these radical groups, as Brown explains: "It is also true that much of the historiography so far has privileged a rather narrow, student Marxism-centric, organization-bound view of the sixties-with a correspondingly narrow view of what constitutes "politics" — which has left out important parts of the picture." ${ }^{49}$ This indicates that the political complexities of everyday life in the 1968 movements are often glossed over. Wolfgang Seidel seems to agree with this sentiment when he says that "the jingle-jangling, weed smoking musicians are not even present in the K-Group historiography of 1968." conception of the Scherben: They saw themselves as musicians and artists, not part of the "K-Group

\footnotetext{
${ }^{42}$ Ibid., 9. See also Sichtermann, Keine Macht für Niemand, 58.

${ }^{43}$ Sichtermann, Keine Macht für Niemand, 57.

${ }^{44}$ Agit 883 Nr. 73 (Berlin), December 24, 1970, 5.

${ }^{45}$ Agit 883 Nr. 73 (Berlin), December 24, 1970, 5; translated by Brown, “Music as a Weapon?," 18.

${ }^{46}$ Rio Reiser and Hannes Eyber, Rio Reiser. König von Deutschland. Erinnerungen an Ton Steine Scherben und mehr. Erzählt von ihm selbst und Hannes Eyber (Cologne: Kiepenheuer \& Witsch, 1997), 163.

47 The Rote Armee Fraktion (RAF, Red Army Faction) was a German extremist leftwing terrorist group that existed roughly from the mid-1970s to the late 1990s. The group was responsible for a series of murders, arsons, bombings, and kidnappings throughout its various iterations.

${ }^{48}$ Sichtermann, Keine Macht für Niemand, 156.

${ }^{49}$ Brown, "Music as a Weapon?," 2.

${ }^{50}$ Wolfgang Seidel, interview, June 22, 2018.
} 
historiography." This stance, however, does not make them apolitical, especially not in the leftist scene of the 1970s. The lifeworld of the Scherben was a complex network of intersecting and often contradictory ideologies. And while they located themselves firmly in the leftist spectrum, that did not shield them from the political trench warfare within. Criticism of the political and artistic direction of the Scherben was constant and relentless. For example, an article from the leftist underground magazine $B U G$ Info scolds them for cooperating in the 1976 election campaign of the social democratic party SPD, for which the band wrote songs, but did not directly participate in. ${ }^{51}$ The article calls out the supposed hypocrisy of this engagement and accuses the Scherben of taking the "dirty banknotes" 52 of the SPD. The Scherben were for a time confronted with critical chants and banners at their concerts. It is not difficult to understand this audience reaction, since the West-German radical left (especially in Berlin) tended to be somewhat possessive of the Scherben, and considered them a mouthpiece for their ideologies:

The leftist comrades used the Scherben, as Rio put it, like a kind of traveling music box, to turn on people and to represent their respective programs. On the other hand, the Scherben were bombarded with all kinds of suspicions, allegations and accusations, to the effect that they were not conforming to the leftist movement, whatever that meant. ${ }^{53}$

So, the Scherben were often the target of criticism within the left. Brown interprets this as the result of an underlying conflict:

Ton Steine Scherben's thorny relationship with the dogmatic left reflected a basic tension at the heart of left-wing activism, one that revolved around questions of revolutionary organization and tactics. This tension found its reflection in the basic and long-standing split between statist and anarchist versions of socialism. ... In Germany, the erasure of the left's past by the experience of Nazism meant that that past—along with these fundamental conflicts—had to be discovered anew. ${ }^{54}$

It is quite significant that even this intra-left conflict in the 1960s and 1970s was impacted significantly by the reverberations of the war-specifically by the loss of memory.

The cultural and political lifeworld of the Scherben especially in the early 1970s was a complex network of commitments, clashing ideologies, conflicting personal interests and differing ideas about artistic expression and integrity. It was a time made no easier by the older generation's avoidance of the topic of WWII or their refusal to discuss certain issues. In the following chapter, I will discuss some examples of how the Scherben's criticism of everyday interaction between the generations relates back to the issue of the coalition of silence and the continued presence of Nazi ideology in the 1970s West German lifeworld.

\section{Memory reverberations in the Scherben's cultural production}

The Scherben's most overtly political albums are no doubt their first two releases-Warum geht es mir so dreckig? (Why do I feel so bad?, 1971) and Keine Macht für Niemand (No power to no one, 1972). While their later productions generally moved away from politics and towards more personal or esoteric topics, each album retained political qualities. So it would be wrong to argue that the Scherben entirely

\footnotetext{
${ }^{51}$ Sichtermann, Keine Macht für Niemand, 162. However, both Kai Sichtermann and Wolfgang Seidel, at that point not officially members of Ton Steine Scherben, were musicians in the band Captain Hammer, which was put together for the election campaign (ibid.).

52 Ibid., 166.

${ }^{53}$ Ibid., 167.

${ }^{54}$ Brown, "Music as a Weapon?," 13.
} 
distanced themselves from politics after their move from Berlin to rural Fresenhagen in 1975 to form a commune. ${ }^{55}$ That being said, it is probably uncontroversial to argue that the Scherben's first two albums contained their most radical songs. Both albums were produced with minimal budget and preparation, ${ }^{56}$ which explains their rough, almost punk-sounding quality. Brown says about the Scherben's first album: “The title of the group's first album, Warum geht es mir so dreckig (1971), captured perfectly the group's concern with exploring the subjectivity and psychology of oppression rooted in the experience of daily life." The description is fitting, as we shall see in the analysis.

The song "Macht kaputt, was euch kaputt macht" (Destroy everything that destroys you, 1971) from the first album was also the A-side of the Scherben's first single in $1970 .^{58}$ The single was a success and consolidated the Scherben as a household name in leftist scenes in Germany. ${ }^{59}$ The song lyrics themselves were not written by the Scherben, but by Hofmann's Comic Teater member Norbert Krause, influenced by Bob Dylan's "Subterranean Homesick Blues" (1965) ${ }^{60} \mathrm{I}$ am discussing the album version of the song here, a live recording, which is played in direct conjunction with Bertolt Brecht's and Hanns Eisler's "Einheitsfrontlied" (United Front Song, 1935). ${ }^{61}$ Asked about this juxtaposition, Kai Sichtermann told me:

We were all very radical in the beginning. But that faded a bit. And at some point we thought, we didn't really like the word "kaputt" [normally "broken," but here in the sense of "destroy"; author's note] much anymore. So we wanted to soften it a bit. Thus we put [the Einheitsfrontlied] onto it, to take out the abrasiveness a bit. ${ }^{62}$

It might seem surprising that the Scherben, given their anti-authoritarian stance, would consider any of their songs too radical to be played on its own. But the radical nature of this song haunted the Scherben for years; it had lasting consequences for the band's financial situation, because it did not sit particularly well with radio or TV at the time. ${ }^{63}$ Brown calls the song "an iconic expression of rage and violent resistance against the multiple oppressions of daily life." ${ }^{64}$ This is a fairly apt description of it on the surface, but depending on which way one looks at it, there is more to it than that.

The song consists of three verses and three choruses. All three verses are constructed vaguely in the countdown-style of Dylan's "Subterranean Homesick Blues." Both the first and second verse of the song show an anti-capitalist/anti-consumerist stance. Verse one references playing radios, LPs and TVs, as well as the purchase of cruises, cars, houses and furniture, and then asks "for what?". Verse two shifts the focus to movement and production, references moving trains and dollars, working people and machines, motors and cannons being constructed, ending with the question "for whom?". Finally, verse three references flying bombers, violent police, dying soldiers, then talks about stocks, bosses, law and state being protected

\footnotetext{
${ }^{55}$ Sichtermann, Keine Macht für Niemand, 144. The reasons for the move related to the possessiveness with which the West Berlin left treated the Scherben, as well as a number of financial and other issues. See Sichtermann, Keine Macht für Niemand, 138).

${ }^{56}$ Ibid., 29, 56, 89.

${ }^{57}$ Brown, "Music is a Weapon?," 8.

${ }^{58}$ The song's lyrics were also published in an issue of Agit 883 in April 1970 (cf. 1970: 1).

${ }^{59}$ Sichtermann, Keine Macht für Niemand, 25.

${ }^{60}$ Ibid., 17.

${ }^{61}$ Helmke Jan Keden, “'Kommst du auch zum Kaffeeklatsch?’ Ein Beitrag zur 'Arbeitersängerbewegung' im Nationalsozialismus.” International Journal of Musicology 8 (1999), 317.

${ }^{62}$ Kai Sichtermann, interview, August 20, 2018.

${ }^{63}$ Sichtermann, Keine Macht für Niemand, 25.

${ }^{64}$ Brown, "Music is a Weapon?," 3.
} 
(presumably by police), then ends with "from us!". ${ }^{65}$ The verses are separated by the chorus, which is repeated twice each time, before the song transforms into the "Einheitsfrontlied."

The music in general is rather dissonant. The song is in the key of A minor, and the main riff (which plays throughout almost the entire song) relies heavily on the tension of a tritone (in the progression A-E$\mathrm{Eb}$, then A-D-C), used here as a carrying note instead of a passing note. This gives the riff a foreboding dissonance. The vocals are very harsh, more shouted than sung, in keeping with the abrasiveness of the performance.

While the song is certainly an expression of rage, it is not directionless rage. The target of this anger is the upper class, from bosses and judges to politicians. This upper class is juxtaposed with "us" (most likely meaning working classes and/or leftist youth), from whom the upper class is being protected. On a surface level, the song is a fairly simple "us versus them" narrative, meaning working class/leftist youth against capitalists/politicians. But to my mind, what makes this song so powerful is that presupposing knowledge about WWII in the listener (which we can do for the 1970s German audience), it changes its meaning from "an iconic expression of rage" to a description of the oppressiveness of a capitalist/fascist system. People are caught in the production/consumption apparatus of the capitalist state, as described in the first two verses; this is juxtaposed with the arming and protection processes in verse three. They are at the same time engaged by the capitalist system and prevented from changing their situation by violent means. The threat of this scenario is emphasized by the foreboding quality of the dissonant tritone riff and the angry screams of Rio Reiser's vocals.

Initially, there is no indication that this song relates to WWII or fascism at all, since there is no explicit reference to it. That changes when the "Einheitsfrontlied" enters the picture. The "Einheitsfrontlied" is a de facto antifascist song, indeed it was written with the intention to help relax the conflicts between various leftist factions and to focus attention on the common fascist enemy. ${ }^{66}$ Memory now becomes key to the interpretation: Despite Sichtermann's pragmatic reasoning for the pairing of "Macht kaputt, was euch kaputt macht" and the "Einheitsfrontlied," it nevertheless directly connects the youth resistance of the 1970s with memory of the antifascist resistance of the 1930s (implying by reverberation that the 1970s youth is now fighting another fascism; the 1930s resistance echoes in the 1970s resistance). Scherben's version of the "Einheitsfrontlied" retains the harshness of "Macht kaputt, was euch kaputt macht." The songs transition into one another with one guitar holding an A chord over a few measures, while the other guitar introduces the marching rhythm accompaniment of the "Einheitsfrontlied," which then continues through most of the song. The "Einheitsfrontlied" remains in the key of A minor in accordance with "Macht kaputt, was euch kaputt macht." The tritone riff returns at the end of the "Einheitsfrontlied;" this gives both songs a certain unity and reinforces the equation between 1930s and 1970s leftwing resistance. Both the combination of the songs as well as the musical strategies employed in connecting them indicate not just the connection to the historic antifascist resistance, but also the continuities of the fascist past in the capitalist present.

Looking at the second album, there is no shortage of songs that could be argued to relate to WWII memory in the same way that "Macht kaputt, was euch kaputt macht" does. Keine Macht für Niemand (1972) is in many ways a continuation of Warum geht es mir so dreckig?, in that it covers many of the same themes. Robb reads the songs of the album as narratively connected:

\footnotetext{
${ }^{65}$ Ton Steine Scherben. Geschichten Noten Texte und Fotos aus 15 Jahren. Kreuzberger Hefte VI(Berlin: Dirk Nishen Verlag in Kreuzberg, 1985), 23.

${ }^{66}$ Keden, "Kommst du auch zum Kaffeeklatsch?," 317. The "Einheitsfrontlied" is a marching song with a clear communist message, its lyrics calling on workers to join the march for equality, justice and the fulfillment of basic human necessities.
} 
Lead singer Rio Reiser is the squatter anarchist. Each song tells a different story of life in their community: street battles with police; occupying houses; dodging fares on the Berlin public transport system; the communal squat as a haven from the boredom of apprenticeships; the quest for freedom from the constraints of the post-war economic miracle; the longing for utopian alternatives to capitalist reality. ${ }^{67}$

While probably not intended as a concept album, certainly the album's themes are rather coherently related to one another. The seeming conceptual unity of the album is most likely a result of the way the Scherben lived and interacted with their surroundings, through which many of the themes are informed. Robb neatly summarizes these concepts:

In the songs, the demand for freedom is frequently juxtaposed with the social restrictions which prevent this. Freedom is embodied by the political struggle on the streets, the communal life of the squats, and the willful violation of rules and regulations. Rules and regulations are represented by the workplace, the family home, institutions, and figures of authority such as politicians, factory bosses, and parents. ${ }^{6}$

We have already seen the juxtaposition of freedom versus social restrictions in "Macht kaputt, was euch kaputt macht" in the surface-level "us versus them" narrative. On Keine Macht für Niemand, this trend is continued. Many, if not most of the songs on the album are reflections of this topic; most of them are consequently also examples of the Scherben's handling of memory reverberations (given that the social restrictions that Scherben criticize are at least partially the result of the war and its fallout, in that it caused many people from the war generation to revert to conservative values). In my analysis, I will limit myself to the song from the album that to me stands out as the most obvious example of the handling of memory reverberations.

"Menschenjäger" (Man hunters) on the surface is a song dealing with authoritarianism, and one of the very few that contains direct references to the war. It is an overall attack on every figure of authority, and a defiant call for resistance. It directly associates the politically motivated violence perpetrated by police and state (by "Menschenjäger" and "Schreibtischtäter," desk murderers) with the violence perpetrated by the Nazis. Despite the fact that the lyrics contain unmistakable references to fascism and neo-fascism, Kai Sichtermann maintains that the song was rather about the politics of the time:

Back then there were Strauss and such people .... Yes, Genscher was already there, Stoltenberg, Barschel. ... And of course they heavily attacked the leftist students, of whom there were quite a lot in those days. . . the things with the K-Groups were also already starting at the time. And at some point there was the RAF. The whole drug scene, Umherschweifende Haschrebellen [Roaming Hash Rebels] and so on, the right-wing conservative politicians obviously were railing against that. ... Exactly, and we fought against that. That's how "Menschenjäger" developed. ${ }^{69}$

So, according to Sichtermann, the song directly concerns a number of right-wing conservatives who

\footnotetext{
${ }^{67}$ Robb, “The Early Protest Song," 53.

${ }^{68}$ David Robb, "Ernst Busch, Rio Reiser, and Gerhard Gundermann: Examples of Proletarian Narrative Role-Play in German Political Song," in Lied und Populäre Kultur/Song and Popular Culture. Jahrbuch des Zentrums für Populäre Musik und Kultur. 60./61. Jahrgang - 2015/2016. Musik und Protest/Music and Protest, ed. Knut Holtsträter and Michael Fischer (Münster: Waxmann, 2016), 235.

${ }^{69}$ Kai Sichtermann, interview, August 20, 2018. All of the men mentioned here were members of either the CDU/CSU or FDP and active in politics at the time of the album release. Of the names mentioned, only FDP politician and (at the time) minister of interior Hans-Dietrich Genscher is mentioned by name in the lyrics. However, the last verse contains several other names, such as Nixon, Krupp, and Springer, just to mention the well-known ones. So the criticism of conservatives in the song is not limited to the FRG or just politics, but also concerns the US as well as industry and conservative press.
} 
opposed the youth/student movements. The song is somewhat unusual in the work of the Scherben, because it discusses large-scale politics as opposed to the small-scale authoritarianism and conservatism that were more usually the topic of the Scherben's songs at the time.

The song consists of three verses and three choruses; the last verse and chorus are more than twice as long as the others but sung over the same riffs. It begins with the sound of police sirens and machine gun fire, before the main piano riff is introduced (the progression E-F\#-G/C-B-A-F\#), which is also used for the end of the chorus (preceded by a continuous A-E change). The last chorus is followed by an extensive guitar solo, which is mixed with the sounds of gunshots and air raid sirens. The song then ends with Reiser counting from one to eleven and then singing, "seht die Zeiger auf der Uhr / Papiertiger" (see the hands of the clock / paper tiger) over the chorus.

The main riff and chord progression in the verse (B-G-B-G-F\#/A-E-F\#-G-B) give the track a gloomy quality. The usage of the lower registers on the piano adds to this impression. The guitar is heavily distorted and overlaid with a wah-effect. It follows along with the piano riff and occasionally plays embellishments. Robb has described the song as follows:

There is also an air of experimentalism: distorted guitars—a hallmark of early 1970s progressive rock-are used to augment the soundscape of chaos. Sound effects such as sirens and gunshots (as in Menschenjäger) denote street battles between urban guerrillas and police. ${ }^{70}$

The police siren at the beginning of the song combined with the sound of machine gun fire may possibly invoke the context of urban fighting, but more significantly, it must have reminded leftist listeners in the 1970s (specifically those from Berlin) of the deaths of fellow (leftist) youths Benno Ohnesorg (d. 1967), Georg von Rauch (d. 1971), and Thomas Weisbecker (d. 1972), ${ }^{71}$ which were caused by police and widely covered in German media. Additionally, the sound of the air raid sirens over the solo would probably rather invoke associations with WWII and bombings in a 1970s German audience than guerilla fighting. This combined use of sound effects thus enforces the association between the 1970s FRG state and the Nazis.

At its most basic level, the song again follows an "us versus them" narrative, pitting leftist youth and working class against the oppressive "Menschenjäger" and "Schreibtischtäter." The extension of verse and chorus give an impression of escalation, as if the lyrical subject is worked up over the issues and is now yelling at the "Menschenjäger" and "Schreibtischtäter." This matches the shouted vocals and the "calling out' of the "Schreibtischtäter" at the end. At the same time, the lyrical subject is speaking both to and as a spokesperson of "us," that is, leftist youth/working class. The pronoun "us" refers to a sense of community, implying that listeners share the anger and frustration of the lyrical subject about the continuities of the Nazi past. By pointing out these continuities (I address below whether they are real or perceived), the Scherben use the memory of the war in an effort to unify the "us" under a common banner of systemic criticism.

The "Schreibtischtäter" are relatively clearly implied to have a specific pedigree. The lyrics contain specific references to WWII and the Nazi regime. The first line of the second verse mentions the "Führer," the last chorus contains references to fascists (in the same line that mentions sadists and the CIA), the farright party NPD, and "Kriegsgewinnler" (war profiteers), meaning industrial magnates and others who profited from the war. All are described as "Menschenjäger" and "Schreibtischtäter." The latter term is of

\footnotetext{
${ }^{70}$ Robb, "Ernst Busch, Rio Reiser, and Gerhard Gundermann,” 234.

${ }^{71}$ Benno Ohnesorg was a student who was murdered by policeman (and secret GDR informant) Karl-Heinz Kurras during a demonstration against a state visit of Iranian Shah Mohammed Reza Pahlavi in 1967. Georg von Rauch and Thomas Weißbecker were militant leftists shot by police while trying to resist arrest. All three of them were considered martyrs to the West German leftist cause in the 1970s. Von Rauch and Weißbecker had occupied houses in Berlin named after them.
} 
specific interest here: probably the most infamous German "Schreibtischtäter" was Nazi officer Adolf Eichmann, who planned and organized the systematic deportation and murder of Jews from his desk. Eichmann was caught by the Mossad in Argentina and then tried and executed in Israel in 1962, a trial and verdict that were widely reported upon in Germany (and worldwide) at the time. This likely gave the term "Schreibtischtäter" an additional, sinister connotation even in 1972.

Another such reference is contained in the third line of the first two choruses, "die uns millionenmal ermordet haben" (those who murdered us by the millions). In conjunction with the first two lines of the chorus, "Ich mein die Menschenjäger / und die Schreibtischtäter" (I am talking about the man hunters / and the Schreibtischtäter), this line can be understood to refer to the Holocaust. The "us" in line three identifies the lyrical subject (and therefore leftist youth/working class) directly with the victims of the Nazi regime.

"Menschenjäger" is an emphatic example of the effects of the past war on the 1970s present in Scherben's music. The frequent use of unambiguous references to the war pulls its subtle presence in the 1970s lifeworld out in the open, and the attack on the "Menschenjäger" and "Schreibtischtäter" not only puts them in line with the perpetrators of the fascist past, it establishes a direct pedigree between them and the fascists. Whether this is a logical thought, considering the accused mentioned by name also include the CIA and Richard Nixon, is beside the point. All of them are considered "war profiteers" and thus part of the same capitalist/fascist machine. This is of course a sweeping generalization, but the song is not about logic and reasoning; instead, it is about anger, and part of that anger is directed at the fact that more than thirtyfive years after the war, people find themselves terrorized by the same type of "Schreibtischtäter." As mentioned above, constructions of a Nazi pedigree need not necessarily be real to be effective. In this way, the song is very much about the presence of the past in the present; the "Menschenjäger" and "Schreibtischtäter" are personifications of memory reverberation, white-collar fascists.

For the third and final example, I will discuss the song "Jenseits von Eden" (Beyond Eden, 1981). "Jenseits von Eden" is another song in which the war is (more or less) directly referenced. Wolfgang Seidel said in an interview in 2002:

You clearly have to view this from the context of the 1960s. This was the time when Peter Weiss for example staged a play about the Auschwitz trial, a time when such plays still provoked public discussion. Where all the Nazi past in general, which had been suppressed for twenty years, suddenly boiled over. In the lyrics of the Scherben-also the later ones which are often portrayed as unpolitical—all these things are present. A text like "Jenseits von Eden" is a political text. It contains a clear reference to Auschwitz. The wheels rolling through the night as described in the text are the trains to Auschwitz. Such things were very present in the thinking of the Scherben. ${ }^{72}$

"Jenseits von Eden" is a later Scherben song, published in 1981 on the fourth Scherben studio album IV (also called Die Schwarze, The Black One), an album significantly less overtly political in general terms compared to the earlier albums; however, references to war and politics are still present in the songs, reflecting the Scherben's lifeworld at the time. The lyrics of "Jenseits von Eden" itself may seem disjointed and associative at first glance; it is difficult to say what the song is about. It references the Old West, Euphrates and Tigris, Allah, the Ten Commandments, the number 666, the war, living in the city, and other seemingly unconnected subjects, at one point even containing the phrase "Ich hab den Text vergessen" (I forgot the lyrics). The text was written in reference to a tarot card, the wheel of fate; certain numbers and

\footnotetext{
${ }^{72}$ Martin Büsser, "Vom Verfassungsfeind zum Deutschen Aushängeschild. Ton Steine Scherben,” in testcard \#12: Linke Mythen, ed. Roger Behrens, Martin Büsser, and Johannes Ullmaier, (Berlin: Ventil Verlag, 2003), 9.
} 
references in the song are supposed to conjure up the "Schicksalskreis des Daseins" (the circular fate of Being). Hannes Eyber, one of the lyricists, is quoted as saying that due to time restrictions, the text is the result of the writers, himself and Rio Reiser, throwing together phrases from their note cards. ${ }^{73}$

Authorial intent (or conscious non-intent) notwithstanding, what concerns us here for now are the lines that Seidel references in the interview, and a few others that seem connected to the context of war and/or persecution. These are (in order of appearance): "Schütze uns vor gestern" (protect us from yesterday); "Eins Neun Dreiunddreißig" (one nine thirty-three); "Wo warst du im Krieg" (Where were you in/during the war); "Weißt du was ich meine" (do you know what I mean); "Du warst auf der Suche" (you were searching); "Ich war auf der Flucht" (I was fleeing); "Hörst du die Räder rollen" (do you hear the wheels roll); "Durchsichtig und klar" (transparent and clear); "Irgendwann in der Nacht" (sometime in the night). The rest of the lyrics conjure up similarly disjointed imagery, but (at least initially) may not seem related.

The first pair of lines gives the song a rather strong implication of a connection to WWII. The line "one nine thirty-three" spells out the year 1933, which in German collective memory is almost inevitably connected to Hitler's seizure of control in the Weimar Republic. The preceding line "protect us from yesterday" in conjunction with "one nine thirty-three" may be interpreted a warning of the return of fascism, as Seidel argues. ${ }^{74}$

The second set of lines is a direct reference to Nazi persecution, even though at first glance it may not be obvious. The question "where were you during the war" was still a delicate issue during the 1980s, only in part occasioned by the coalition of silence. Some people in Germany-like the fictional person addressed in the lyrics (as indicated by the following lines) — had more nefarious reasons than others to conceal their wartime occupations. The following line "do you know what I mean" indicates that the lyrical subject already knows about the past of the person the question is addressed to: an SS- or Gestapo officer searching for dissidents or other groups persecuted by the Nazis. The next two lines draw a comparison: "you were searching" and "I was fleeing," constituting the speaking subject as part of the persecuted, and the person spoken to as the persecutor. For the next line, "do you hear the wheels roll," I will follow Seidel's interpretation; the line references the trains to Auschwitz. This interpretation impacts the last two lines, "transparent and clear" and "sometime in the night." The trains being described as transparent references the argument of many Germans after the war that they had not known what was being done to the victims of the regime after their deportation. This is also why they are described as traveling during the night, when those Germans were sleeping soundly, apparently blissfully ignorant of the cruelties committed.

Musically speaking, the song is very forceful. The snare almost continually emphasizes every quarter note in the $4 / 4$ meter and pushes the music forward. This creates a stomping rhythm that could indeed be associated with the chuffing of a rolling train, which puts an emphasis on that particular part of the lyrics. The synth piano plays mostly on the offbeats and so supports the impression of chuffing. The guitar largely stays on the snare beat, but occasionally diverges from it to play a chord that rings out over the course of a measure. After two full recitations of the text, the song opens up (although the stomping snare beat continues) to allow for guitar and piano solos until the track goes to fade. The rushing tempo of the music, the chuffing rhythm of the drums and the occasional solo interlude evoke the sense of the listener having just hitchhiked on someone's literal train of thought—a train that passes beyond Eden, or in other words,

\footnotetext{
${ }^{73}$ Sichtermann, Keine Macht für Niemand, 288.

${ }^{74}$ Seidel, "Scherben...," 107.
} 
through the FRG.

When considering the relationship of music and lyrics, the song manifests a third layer of meaning: the staccato rhythms of both drums and vocals give the lyrics a droning quality, akin to a prayer of mourning or lament. The repetition of the lyrics adds to this impression. This reframes the various religious/biblical references throughout the text (some of which are mentioned above). The train of thought we have hitchhiked becomes one of a bereaved person in mourning about those lost to Nazi persecution and holocaust. At the same time, those lines entirely unrelated to the context of persecution and mourning reflect both the struggle to remember in a country that obscures its past and the ultimate impossibility to recognize or understand the sheer scale of the loss itself. Random bits of thought float in and out of the consciousness of the mourner, indicating the failure to take it all in or make any sense of it.

This is, simply put, memory reverberating. As Seidel has pointed out, war and persecution were very present in the thinking of the Scherben. Furthermore, the search for old Nazi criminals was not over by the time IV came out; indeed, it continues to this day. These were topics of political conversation; the hunt for Nazi perpetrators was reported on in the news and talked about in pubs, specifically in leftist contexts. They were part of the historical framework the Scherben, as a politically conscious band, picked up on. Even though the lyrics were ostensibly constructed arbitrarily, the song as a whole illustrates that while the lifeworld of the Scherben is governed by other thoughts and topics, the memory of WWII is still a major (and largely unresolved) issue in the (un)conscious of many Germans at the time.

Generally speaking, an aspect of note in the Scherben's lyrics is how WWII and fascism are referenced. References to the Nazis in general are not unusual for the leftist scene. In fact, Nazi-comparisons were very common within leftist circles in the FRG. The government, the (Springer) press, the police, the US, even other leftist circles were regularly compared to the Nazis (a perusal of leftist underground magazines like Agit 883 will confirm this). ${ }^{75}$ These comparisons were so common they were essentially part of the everyday rhetoric in the leftist scenes (and judging from my own observations, they are not unusual even today). It is therefore not particularly surprising that the Scherben incorporated such comparisons (as in "Menschenjäger"). Seidel emphasizes the tendency of the Scherben to pick up on discursive trends:

The lyrics of the Scherben were a mirror of what was hotly being discussed at the time. The Scherben often picked up sentences which were already prevalent in the scene: "Macht kaputt, was euch kaputt macht" was written in one of the leaflets of the "Zentralrat der umherschweifenden Haschrebellen" [Central Committee of the Roaming Hash Rebels], "Keine Macht für niemand" was from a comic in an underground newspaper."

This is a major aspect of the Scherben's cultural production: their music was in part a reflection of whatever was being discussed at the time. They would pick up on slogans and discussions and write songs around them. This almost naturally led to the Scherben also reflecting the gap where the memory of the war should have been. Analogies are woven into the Scherben's music via the illustrations of the social and cultural fallout stemming from the war and the oppressive silence that surrounded it. This is memory reverberation, not memorialization. As much as the Scherben were a mirror of leftist discursive practice at the time, they also reflected how problematic and inhospitable many aspects of the German lifeworld had become because of this refusal to deal with the past.

\footnotetext{
${ }^{75} \mathrm{I}$ feel it is necessary to add here that the fact that leftists were comparing people to the Nazis does not contradict the proposition of the coalition of silence; on the contrary, attacks like these were what required the coalition of silence to create new narratives for the circumvention of the topic.

${ }^{76}$ Seidel, "Berlin," 44.
} 


\section{Conclusion}

The Scherben were a phenomenon that profoundly changed the musical and cultural landscape of West Berlin in particular and Germany in general. While their influence (measured in terms of reach and commercial success) may fall behind other German-language acts that followed in their footsteps, the radical nature of their cultural production and their political relevance to both their audience and their political adversaries cannot be overstated. The longevity of their music and messages, reflected in the continued public use of their music at demonstrations and in leftist pubs and parties, the innumerable cover versions, and not least the continued coverage of their history in books, films, theater, and TV documentaries, is more than enough evidence of their long-term effect on the German musical landscape. Judging from my personal experience, while some Germans today might not have heard the name Ton Steine Scherben, they almost certainly will be familiar with at least one song from either the Scherben or Rio Reiser.

The Scherben's creativity in handling the memory of WWII in 1970s Germany did go a long way to provide their audience with an understanding of their lifeworld (and specifically that lifeworld's relationship to its past), from which they could challenge outdated notions of obedience and authoritarianism. To my mind, this is also part of the reason why the Scherben are still so actively listened to and utilized at (leftist) political events. The creative use of reverberation via the illustration and critique of the effects of that past in the present (even if this practice of memory reverberation was not necessarily intentional) is not just a unique take within the context of the then-nascent German rock music-it is also highly unusual in terms of an artistic approach to memory in general. It represents a facet of sounding memories in that it accounts for those memories that a society would much rather forget but simply cannot. The Scherben's music illustrated problematic conditions in the FRG, and through that, they forced people to reflect upon where these conditions came from. For them, and for their young audience, their vocal acts of liberation were a vital necessity in a world possessed by a past they had had no part in and never wanted to repeat.

The astonishing force of this past, its hold on at least the politicized parts of the 1970s West German youth and their lifeworlds is reflected prominently not just in much of the Scherben's cultural production, but also in the stories of contemporary witnesses, as I have shown. This indicates the significance of memory reverberation as a phenomenon, certainly in West Germany at the time, but perhaps even in more general terms. The myriad large and small ways an unspoken, uncomfortable, or unwelcome past may affect a society at large would be impossible to recount; but there can be little doubt that in this case, it had quite significant effects. Again, memory is not necessarily something an individual or a society wants to have. Just as often, people would rather prefer to be rid of it, "to do nothing, to not even think about it." Memories can be painful, shameful, traumatic, and sometimes seemingly impossible to deal with. That is why both people and societies will sometimes try to make them go away-by ignoring them, by talking around them, or by pretending the dreadful thing that happened was either not so bad, or simply has not happened at all (even the Scherben were to an extent affected by this, as illustrated by the fact that they most often only alluded to WWII in their songs). There may be numerous reasons for such willful oblivion, but the simple fact is that for a past to be forgotten, all traces of it, all the echoes it leaves in the ever moving now, would have to be destroyed. And I think my example here demonstrates quite succinctly that destroying echoes might not be as easy as simply not speaking, because the things people do make sound as well. The construction of deflection narratives, the treatment of youth, and the reaction of that youth-all of these quite impactful things are to a certain extent the results of reverberating memory, echoes in a silence that longs to be filled. 
And if there was one thing the Scherben could do, it was to fill a silence.

As we have seen throughout this article, the afterlife of WWII and its atrocities does reflect quite significantly in the work of the Scherben. Even if Germany in the 1970s did not (and could not) have the memory culture it has today, it has become clear that the war and its atrocities did reverberate and thus affect German society. Memories covered with a blanket of silence came back echoing angrily in the music of the youth. It can be (and has been) $)^{77}$ argued that even the phenomenon of Krautrock with its experimental soundscapes is in some ways a reflection of this reaction to the suppression of memory. The generation of the Scherben were not the first to crack the shell of this silence, nor perhaps were they the most effective in doing so. But they were certainly loud, and by their very critique of the cultural and social conditions their audiences were suffering from, they showed that, as Theodor Adorno had stated, "es gibt kein richtiges Leben im falschen" (there is no right life in the wrong life). ${ }^{78}$

\section{Discography}

Dylan, Bob. Bringing It All Back Home. Recorded 1965. Columbia. LP Record.

Ton Steine Scherben. Warum geht es mir so dreckig? Recorded 1971. David Volksmund Produktion. LP Record.

Ton Steine Scherben. Keine Macht für Niemand. Recorded 1972. David Volksmund Produktion. LP Record.

Ton Steine Scherben. IV (Die Schwarze). Recorded 1981. David Volksmund Produktion. LP Record.

\section{Bibliography}

Adorno, Theodor Wiesengrund. Minima Moralia: Reflexionen aus dem beschädigten Leben. Berlin: Suhrkamp, 1951.

Agit 883 Nr. 57 (Berlin), April 24, 1970.

Agit 883 Nr. 73 (Berlin), December 24, 1970.

Barwell, Ismay. "Understanding Narratives and Narrative Understanding." The Journal of Aesthetics and Art Criticism 67, no. 1 (2009): 49-59. https://doi.org/10.1111/j.1540-6245.2008.01334.x.

Brown, Timothy. "Music as a Weapon? "Ton Steine Scherben" and the Politics of Rock in Cold War Berlin." German Studies Review 32, no. 1 (2009): 1-22.

Büsser, Martin. "Vom Verfassungsfeind zum Deutschen Aushängeschild. Ton Steine Scherben.” In testcard \#12: Linke Mythen, edited by Roger Behrens, Martin Büsser, and Johannes Ullmaier, 4-11. Berlin: Ventil Verlag, 2003.

Erll, Astrid. Memory in Culture. Basingstoke, UK: Palgrave Macmillan, 2011. https://doi.org/10.1057/9780230321670.

Giesen, Bernhard. "The Trauma of Perpetrators. The Holocaust as the Traumatic Reference of German National Identity." In Cultural Trauma and Collective Identity, edited by Jeffrey Alexander, Ron Eyerman, Bernhard Giesen, Neil Smelser, and Piotr Sztompka, 112-54. Berkeley: University of California Press, 2004. https://doi.org/10.1525/california/9780520235946.003.0004.

\footnotetext{
${ }^{77}$ Wolfgang Seidel, Wir müssen hier raus! Krautrock, Free Beat, Reeducation (Mainz: Ventil Verlag, 2016).

${ }^{78}$ Theodor Wiesengrund Adorno, Minima Moralia: Reflexionen aus dem beschädigten Leben (Berlin: Suhrkamp, 1951 ), 59.
} 
Goldfarb, Jeffrey. “Against Memory.” In Routledge International Handbook of Memory Studies, edited by Anna Lisa Tota and Trever Hagen, 53-64. London: Routledge, 2016.

Herzog, Dagmar. Sex After Fascism. Memory and Morality in Twentieth-Century Germany. Princeton, NJ: Princeton University Press, 2007. https://doi.org/10.2307/j.ctt4cgbqw.

Keden, Helmke Jan. “'Kommst du auch zum Kaffeeklatsch?’ Ein Beitrag zur 'Arbeitersängerbewegung' im Nationalsozialismus.” International Journal of Musicology 8 (1999): 301-20.

Lohl, Jan. ““...die ganze Nazi-Scheiße von gestern... 'Protest und Phantom-Die Protestbewegungen der 1960er Jahre aus der Perspektive der psychoanalytischen Generationenforschung." In Psychosozial 124: Unheimliche Wiedergänger? Zur Politischen Psychologie des NS-Erbes in der 68erGeneration, edited by Markus Brunner and Jan Lohl, 11-25. Giessen: Psychosozial Verlag, 2011.

Mendívil, Julio. "Schlager and Musical Conservatism in the Post-War Era." In German Pop Music: A Companion, edited by Uwe Schütte, 25-42. Berlin: De Gruyter, 2017. https://doi.org/10.1515/9783110425727-002.

Moeller, Robert. War Stories. The Search for a Usable Past in the Federal Republic of Germany. Berkeley: University of California Press, 2001.

Müller, Achim. "Eisen erzieht." In Scherben. Musik, Politik und Wirkung der Ton Steine Scherben, edited by Wolfgang Seidel, 115-24. Mainz: Ventil Verlag, 2005.

Noller, Christian. riocover.de. Accessed May 2, 2019. http://www.riocover.de/1.htm.

NS-Dokumentationszentrum der Stadt Köln. "HJ-Lieder von Hans Baumann.” Jugend! Deutschland 1918-1945. Accessed October 24, 2020. https://jugend19181945.de/portal/jugend/thema.aspx? root $=26636 \&$ id $=4922$.

Reiser, Rio, and Hannes Eyber. Rio Reiser. König von Deutschland. Erinnerungen an Ton Steine Scherben und mehr. Erzählt von ihm selbst und Hannes Eyber. Cologne: Kiepenheuer \& Witsch, 1997.

Rigney, Ann. "Cultural Memory Studies. Mediation, Narrative, and the aesthetic." In Routledge International Handbook of Memory Studies, edited by Anna Lisa Tota, Trever Hagen, 65-76. London: Routledge, 2016.

Robb, David. "Ernst Busch, Rio Reiser, and Gerhard Gundermann. Examples of Proletarian Narrative Role-Play in German Political Song." In Lied und Populäre Kultur/Song and Popular Culture. Jahrbuch des Zentrums für Populäre Musik und Kultur. 60./61. Jahrgang - 2015/2016. Musik und Protest/Music and Protest, edited by Knut Holtsträter, Michael Fischer, 227-46. Münster: Waxmann, 2016.

Robb, David. "The Early Protest Song of the Late 1960s and Early 1970s_Franz Josef Degenhardt and Ton Steine Scherben,” In German Pop Music: A Companion, edited by Uwe Schütte, 43-61. Berlin: De Gruyter, 2017. https://doi.org/10.1515/9783110425727-003.

Seidel, Wolfgang. "Berlin und die Linke in den 1960ern. Die Entstehung der Ton Steine Scherben.” In Scherben. Musik, Politik und Wirkung der Ton Steine Scherben, edited by Wolfgang Seidel, 25-50. Mainz: Ventil Verlag, 2005.

Seidel, Wolfgang. "Scherben..." In Scherben. Musik, Politik und Wirkung der Ton Steine Scherben, edited by Wolfgang Seidel, 69-114. Mainz: Ventil Verlag, 2005.

Seidel, Wolfgang. Wir müssen hier raus! Krautrock, Free Beat, Reeducation. Mainz: Ventil Verlag, 2016.

Sichtermann, Kai, Jens Johler, and Christian Stahl. Keine Macht für Niemand. Die Geschichte der "Ton Steine Scherben”. Berlin: Schwarzkopf \& Schwarzkopf, 2000. 
Skai, Hollow. Rio Reiser. Das alles und noch viel mehr. Die inoffizielle Biografie des Königs von Deutschland. Bremen: Fuego, 2016.

Squire, Corinne. "Experience-Centered and Culturally-Oriented Approaches to Narrative." In Doing Narrative Research, edited by Molly Andrews, Corinne Squire, and Maria Tamboukou, 41-63. Los Angeles: SAGE Publications, 2008. https://doi.org/10.4135/9780857024992.d4.

Ton Steine Scherben. Geschichten Noten Texte und Fotos aus 15 Jahren. Kreuzberger Hefte VI. Berlin: Dirk Nishen Verlag in Kreuzberg, 1985.

Vens, Hartwig. “'Unsere Lieder sind einfach, damit viele sie mitsingen können.' Zur Sprache der Scherben." In Scherben. Musik, Politik und Wirkung der Ton Steine Scherben, edited by Wolfgang Seidel, 205-214. Mainz: Ventil Verlag, 2005. 